\title{
VARIASI DERMATOGLIFI MAHASISWA DARI PERKAWINAN BERBEDA SUKU DI FKIP UNIVERSITAS LABUHANBATU
}

\author{
Ika Chastanti \\ Fakultas Keguruan dan Ilmu Pendidikan Universitas Labuhanbatu \\ email: chastanti.ika@gmail.com
}

\begin{abstract}
Dermatoglyphics is derived, and each individual has a different fingerprint pattern even if they are born twins. Fingerprint patterns generally divided into three models, namely Arch, Loop, and Whorl. Fingerprints can widely used as a means of identifying a person in terms of biological decline and differences between ethnic groups. The purpose of this study was to determine variations in dermatoglyphics in students at FKIP Labuhanbatu University from different ethnic marriages. The sampling technique in this study is Purposive Sampling. The method of taking fingerprints is done by sticking student fingerprints on a piece of paper using a blue stamp bearing. The type of fingerprint only observes the results of fingerprint collection. The results showed that variations in the types of fingerprint patterns were found in students with Malay-Javanese, Malay-Batak, Javanese-Batak parental by having Arch, Loop, and Whorl. The most commonly found fingerprint pattern is the Loop type, with a percentage of $71.7 \%$ (Javanese - Batak), 61.8\% (Batak - Minang), and 60\% (Aceh - Batak).
\end{abstract}

Keywords: dermatoglyphic, genetics variation, ethnic

\begin{abstract}
Abstrak
Dermatoglifi diturunkan secara poligenik dan setiap individu memiliki pola sidik jari yang berbeda walaupun terlahir kembar. Pola sidik jari secara umum dibedakan dalam 3 pola yaitu Arch, Loop, dan Whorl. Sidik jari secara luas dapat digunakan untuk sarana identifikasi seseorang, dalam aspek biologi penurunannya serta perbedaan diantara suku-suku bangsa. Tujuan penelitian ini adalah untuk mengetahui variasi dermatoglifi pada mahasiswa di FKIP Universitas Labuhanbatu dari perkawinan yang berbeda suku. Teknik sampling dalam penelitian ini adalah Purposive Sampling. Metode pengambilan sidik jari dilakukan dengan menempelkan sidik jari mahasiswa pada selembar kertas dengan menggunakan bantalan stempel berwarna biru. Hasil pengambilan sidik jari hanya diamati tipe sidik jari saja. Hasil penelitian menunjukkan bahwa variasi tipe pola sidik jari ditemukan pada mahasiswa dengan parental Melayu - Jawa, Melayu - Batak, Jawa - Batak dengan memiliki Arch, Loop, dan Whorl. Pola sidik Jari paling banyak ditemukan adalah tipe Loop dengan persentase $71,7 \%$ (Jawa - Batak), 61,8\% (Batak - Minang) dan 60\% (Aceh - Batak).
\end{abstract}

Kata Kunci: dermatoglifi, variasi genetika, suku bangsa

\section{PENDAHULUAN}

Dermatoglifi adalah ilmu bentuk atau pola sidik jari. Dermatoglifi diturunkan secara poligenik. Pola dermatoglifi yang terbentuk tidak akan berubah seiring dengan bertambahnya umur, pertumbuhan, dan perubahan lingkungan. Ada tujuh gen yang berperan yang dapat menyebabkan variasi pola dermatoglifi. Dermatoglifi hanya mengalami perubahan pada ukuran sulur, yang berlangsung sesuai dengan perkembangan tangan dan kaki. Variasi pada dermatoglifi satu spesies berbeda dengan spesien lainnya dan menunjukkan ciri khas dari masing-masing spesies (Siburian, et.al., 2010). Pola sidik jari secara umum dibedakan ke dalam 3 bentuk yaitu Arch, Loop, dan Whorl. Pola Arch merupakan pola lengkungan yang tidak memiliki triradius, pola Loop berbentuk lengkung dan memiliki triradius, pola Whorl berbentuk lingkaran yang memiliki 2 triradius.

Sidik jari terbentuk sejak awal perkembangan embrio yang dimulai pada minggu ke 13 sampai minggu ke 24 (Misbach, 2010). Sidik jari saat ini sudah banyak dimanfaatkan untuk identitas diri dan dalam bidang forensic karena sidik jari manusia tidak ada yang sama di dunia 
ini walaupun lahir dalam keadaan kembar. Ciri khas sidik jari dapat memudahkan untuk melakukan identifikasi. Penelitian penyakit genetika sudah banyak dikembangkan dengan melihat tipe dan pola sidik jari dari masing-masing penderita. Penelitian yang telah terangkum mengenai dermatoglifi adalah Putriani (2006) sidik jari pada pendetita autis yang memiliki pola yang khas, Chastanti (2009) sidik jari pada penderita obesitas, Wati et.al., (2015) menemukan pola sidik jari pada anak-anak penderita tuna netra.

Sidik jari secara luas dapat digunakan untuk sarana identifikasi seseorang, dalam aspek biologi penurunannya serta perbedaan diantara suku-suku bangsa (Ramani, 2011). Keragaman suku bangsa dapat diidentifikasi dengan jelas fenotipenya seperti warna kulit, tipe rambut, dan bahasa yang digunakan (Arif, 2013). Dermatoglifi merupakan Karakter lain yang dapat digunakan untuk identifikasi suku bangsa (Purbasari dan Sumadji, 2017). Indonesia memiliki kurang lebih 500 suku bangsa. Data Badan Pusat Statistik Kabupaten Labuhanbatu Selatan mengkategorikan 6 suku yaitu melayu $(0,47 \%)$, batak $(45,61 \%)$, minang $(0,57 \%)$, jawa $(49,80 \%)$, aceh $(0,15 \%)$, dan lainnya $(3,40 \%)$. Penelitian yang menggunakan sidik jari sebagai salah satu alat identifikasi suku bangsa telah dilakukan oleh Hidayati (2005) yang dilaksanakan pada populasi Jawa dan Papua di Surabaya. Panghiyani et.al., (2006) telah melakukan penelitian tentang sidik jari pada suku Dayak Meratus di Kalimantan.

\section{METODE}

Penelitian ini dilakukan dengan mengambil sampel mahasiswa di FKIP Universitas Labuhanbatu yang merupakan hasil perkawinan berbeda suku bangsa. Teknik sampling dilakukan dengan Purposive Sampling. Metode pengambilan sidik jari dilakukan dengan menempelkan sidik jari mahasiswa pada selembar kertas dengan menggunakan bantalan stempel berwarna biru. Hasil pengambilan sidik jari hanya diamati tipe sidik jari saja. Hasil sidik jari mahasiswa yang berasal dari perkawinan berbeda suku bangsa disusun dalam tabel dan ditabulasi dan dilakukan analisis secara deskriptif.

\section{HASIL DAN PEMBAHASAN}

Penelitian ini memperoleh sebanyak 50 mahasiswa yang merupakan hasil perkawinan berbeda suku yaitu 8 suku Melayu dan Batak, 3 suku Melayu dan Jawa, 12 Jawa dan Batak, 5 Jawa dan Minang, 11 Batak dan Minang, 8 Aceh dan Jawa, 3 Aceh dan Batak (Tabel 1).

Tabel 1. Hasil Perkawinan Beda Suku

\begin{tabular}{lcccc}
\hline No. & Suku Parental & \% Arch & \% Loop & \% Whorl \\
\hline 1. & Melayu - Batak & 20 & 47,5 & 32,5 \\
2. & Melayu - Jawa & 20 & 53,3 & 26,7 \\
3. & Jawa - Batak & 6,6 & 71,7 & 21,7 \\
4. & Jawa - Minang & 0 & 26 & 74 \\
5. & Batak - Minang & 0 & 61,8 & 38,2 \\
6. & Aceh - Jawa & 0 & 47,5 & 52,5 \\
7. & Aceh - Batak & 0 & 60 & 40 \\
\hline
\end{tabular}

Hasil penelitian menunjukkan bahwa persentase pola sidik jari Arch banyak ditemukan pada mahasiswa dengan parental Melayu - Batak (20\%), Melayu - Jawa (20\%), Jawa - Batak (6\%) sedangkan pada mahasiswa dengan parental lainnya tidak ditemukan sidik jari pola Arch. Pola sidik jari Loop banyak ditemukan pada mahasiswa dengan parental Jawa - Batak $(71,7 \%)$ dan Batak - Minang (61,8\%). Pola sidik jari Whorl banyak ditemukan pada parental Jawa Minang (74\%) Aceh - Jawa (52,5\%) dan Aceh - Batak (40\%). Hal ini menunjukkan bahwa terdapat variasi dermatoglifi pada mahasiswa yang memiliki parental dengan suku yang berbeda. Mahasiswa dengan parental Melayu - Batak, Melayu- Jawa, dan Jawa - Batak 
ditemukan ketiga pola sidik jari yaitu Arch, Loop, dan Whorl, sedangkan pada mahasiswa dengan parental Jawa - Minang, Batak - Minang, Aceh - Jawa, dan Aceh - Batak tidak ditemukan pola sidik jari Arch. Penelitian ini menunjukkan bahwa variasi dermatoglifi pada suku Melayu- Batak, Melayu- Jawa, dan Jawa - Batak lebih bervariasi karena memiliki 3 pola sidik jari.

Hukum Mendel I dan II menyatakan bahwa setiap alel akan memisah dan akan berpasangan secara bebas. Variasi tipe pola sidik jari jika diamati pada hasil perkawinan berbeda suku yang paling banyak ditemukan adalah tipe Loop dengan jumlah persentase yang besar karena persebaran tipe sidik jari Loop memang lebih banyak dibandingkang dengan tipe sidik jari lainnya. Pola sidik jari Loop ulnar merupakan pola dasar sidik jari manusia. Namun, ada beberapa gen yang berperan dalam pembentukan sidik jari sehingga polanya mengalami banyak variasi ( Hall, 1989). Pola sidik jari ditentukan sangat kuat oleh faktor genetic, tetapi dalam periode pembentukannya dipengaruhi oleh lingkungan. Beberapa penelitian yang menunjukkan bahwa tipe sidik jari Loop lebih banyak adalah tipe sidik jari pada suku Madura dengan jumlah Loop 100\%, Suku Lampung 90\%, Suku Bali dan Betawi 70\%, Suku Dayak 69\%, Suku Flores 50,59\%, dan Suku Mentawai 50\% (Purbasari dan Sumadji, 2017). Penelitian lain yang sejalan yaitu penelitian sidik jari pada suku Dayak Meratus yang didominasi oleh tipe sidik jari Loop ulnar (67,07\%), whorl (25,54\%), arch (4,62\%), dan loop radial ( $2,77 \%)$ (Panghiyangani et.al., 2006).

Hasil penelitian ini dapat digunakan untuk menentukan variasi dermatoglifi pada keturunan yang berasal dari parental yang berbeda suku. Variasi genetic pada perkawinan yang berasal dari suku yang berbeda akan menghasilkan variasi baru dan penambahan materi genetic pada keturunannya. Penelitian dalam genetika populasi menunjukkan bahwa orang-orang dengan suku yang sama, cenderung memiliki variasi DNA yang mirip satu sama lain. Salah satu dampak dari proses evolusi adalah terjadinya variasi biologis (Hidayati, 2015). Penelitian yang berkaitan dengan sidik jari sering dihubungkan dengan penyakit genetika. penelitian tentang penderita penyakit Diabetes Mellitus ditemukan tipe sidik jari terbanyak adalah tipe Arch. Pola dermatoglifi pada penderita skizofrenia di wilayah Surakarta adalah tipe sidik jari Loop (Sintaningtyas, 2010).

\section{KESIMPULAN}

Penelitian ini menemukan adanya variasi genetic pada mahasiswa yang merupakan hasil perkawian campuran berbeda suku dengan persentase berbeda-beda pada setiap tipe sidik jarinya. Pada parental dengan suku Melayu - Batak, Melayu - Jawa, dan suku Batak - Jawa ditemukan ketiga tipe pola sidik jari yaitu arch, loop, dan whorl. Parental pada suku Jawa Minang, Batak - Minang, Aceh - Jawa, dan Aceh - Batak hanya ditemukan tipe sidik jari Loop dan whorl. Persentase tipe sidik jari terbanyak ditemukan pada tipe Loop dengan persentase terbesar 71,7\% (Jawa - Batak), 61,8\% (Suku Batak - Minang), 60\% (Suku Aceh - Batak), 53,3\% (Suku Melayu- Jawa), 47,5 \% (Suku Aceh - Jawa) (Suku Melayu - Batak), dan 26\% ( suku Jawa - Minang).

\section{DAFTAR PUSTAKA}

Chastanti. I. Pola Multifaktor Sidik Jari pada Penderita Obesitas di Daerah Medan dan Sekitarnya. Skripsi. Medan: Universitas Sumatera Utara.

Hall. J.G., G.F.I Ursula., J.E.Allison. 1989. Handbook of Normal Physical. Toronto: Oxford University.

Hidayati. F. 2015. Variasi Pola Sidik Jari pada Populasi Jawa dan Papua. Jurnal Antrounairdotnet. Vol IV : (1). Hal. 30

Misbach. I.H. 2010. Dahsyatnya Sidik Jari : Menguak Bakat dan Potensi untuk Merancang Masa Depan Melalui Fingerprint Anallysis. Jakarta: Visi Media 
Panghiyangani. R., Rosida L., Kartika Y. 2006. Gambaran Sidik Jari Tangan Suku Dayak Meratus di Desa Haruyan Kecamatan Hantakan Kalimantan Selatan. Proceeding Pertemuan Ilmiah Nasional PAAI- Yogyakarta.

Purbasari K., Sumadji. A.R. 2017. Variasi Pola Sidik Jari Mahasiswa Berbagai Suku Bangsa di Universitas Katolik Widya Mandala Madiun. Jurnal Florea. Vol. 4: (2).

Ramani P., H.J Sherlin., Anuja., P. Premkuman. Chandrasekar., Janaki. 2011. Conventional Dermatoglyphic_Revived Concept. Internationa Journal of Pharma and Bio Science. Vol. 2: (3).

Siburian J., Anggraeni E., Hayati. S.F. 2010. Analisis Pola Sidik Jari Tangan dan Jumlah Sulur Serta Besar Sudut ATD Penderita Diabetes Mellitus di Rumah Sakit Umum Jambi. Biospesies. Vol. 2: (2).

Sintaningtyas. L.J. 2010. Pola Dermatoglifi Tangan pada Pasien Skizofrenia di Rumah Sakit Jiwa Daerah Surakarta. Skripsi. Universitas Sebelas Maret.

Wati. M., Megahati., Sari. W.N. 2015. Pola Khas yang Ditemukan pada Sidik Jari dan Telapak Tangan pada Anak-anak Tuna Netra di Kota Padang. Bioconcetta. Vol 1: (2). 